\title{
The Artist-Teacher
}

Dr Esther Sayers

\section{Summary}

Artists who teach or teachers who make art? To explore the identity of Artist Teacher in contemporary educational contexts the ethical differences between the two fields of art and learning need to be considered. Equity is sought between the needs of the learner and the demands of an artist's practice, a tension exists here because the nurture of the learner and the challenge of art can be in conflict. The dual role of artist and of teacher have to be continually navigated in order to maintain the composite and ever changing identity of Artist-Teacher. The answer to the question: how to teach art? Comes through investigating attitudes to knowledge in terms of the hermeneutical discourses of 'reproduction' and 'production' as a means to understand developments in pedagogy for art education since the Renaissance. An understanding of the specific epistemological discourses that must be navigated by Artist Teachers when they develop strategies for learning serves to explicate the role of art practices in considering the question: what to teach? The answer to which lies in debates around technical skills and the capacity for critical thought.

Key words: pedagogy, art, learning, critical, knowledge, empower, social, interpretation, equity

\section{Introduction}

Artists who teach or teachers who make art? Each evades any singular definition. In short, an artist is someone who makes art, a teacher is someone who enables learning and art education is the field of educational practice in which learners are introduced to art and supported to 
develop the conceptual and technical skills to make artwork of their own. An Artist Teacher is someone who creates art and supports the creative processes of learners.

Our understanding of the Artist-Teacher varies according to the context in which they work, these could be schools, galleries or community settings. There is also a range of nouns used to describe them, teacher, educator, facilitator. The essential components of art education are artist, teacher, pedagogy, knowledge, material skill and context; these are interrelated and their configuration can change. The main instrument of such change, the underlying issue, is an ethical one that separates the role of artist from the role of teacher in relation to the question: what does the learner need? In a school context, this is likely to be governed by assessment regimes; in an art gallery, the needs of the learner may be to do with acculturation into new forms of thinking, risk or challenge to existing ideas; in a community context the needs could be for rehabilitation, empowerment, inclusion through the arts. All this variety of 'needs' must be seen by the educator and acknowledged.

At an early stage in their career, those who have undergone art training think of themselves simply as artists, the role of teaching artist tends to come later and is combined with the development of pedagogic skills. An artist's training introduces them to the practices and discourses within their field (Page, 2012). Those who train to become teachers have to undergo a kind of identity transformation where they emerge from their identity as artists into a new identity as teacher (Adams, 2007). Artist Teacher's need to be art practitioners and educators, a dual identity. Engaging with factual knowledge about the art object as well as exploring issues and concepts. 
The conception of the Artist-Teacher affects the processes of education. Some iterations of Artist-Teacher identity are better than others at supporting the development of learner and teacher. How we educate is crucial as it affects a young person's readiness to be active in the world. The means to produce people in the world who are ready and prepared to be, to know and to interrelate: to be social beings. Art and the discourses of power that surround it are affected by the inherent value of the social in arts production and reception.

Teacher Education programmes provide artists with the pedagogic skills to teach. Postgraduate and Continuing Professional Development programmes support teachers in extending and maintaining their dual identity as artist and teacher. To explore the current context for continuing education for Artist-Teacher's it is useful to look at a brief survey of the history and development of the artist as educator/instructor. I will go on to look at how the Artist-Teacher/Educator/Facilitator role is constructed and explore the subject, knowledge and the question of what to teach and how to teach it.

The key debates informing the construction of the Artist-Teacher are to do with the decision about whether to teach specific technical skills for making art, ones that have been culturally valued in the past or whether to start with the knowledge that the learner brings and formulate an approach to art teaching in response to that. To primarily uphold concern for the individual or for the art. This connects to broader debates about the purpose of education: to empower learners and engage them in a journey of discovery, destination unknown or to acculturate them into predetermined modes of thought. These debates are echoed in the field of hermeneutics which I will return to later. 
Globally the notion of the Artist-Teacher is either an artist who teaches or a teacher in a range of educational situation who also makes art. A teacher who, through practice, has created 'a philosophy for creating and thinking' that is applied to educational situations (Daichendt, 2010, 65). Many Artist-Teachers have been influenced transnationally by their educational experiences, receiving artistic education outside of their country of origin or working in international contexts. As a result, 'artists tend to think of themselves as part of a global network that shares information channels and artistic or curatorial modes of presentation and communication’ (Vella, 2016, xviii).

\section{What is Artist-Teacher?}

Like many other professionals, Artist-Teachers balance their identity as practitioners with the demands of their day to day work. However, the Artist-Teacher persona is in many ways at odds with the teacher persona because of the tensions between pedagogic work and the production of art. One of the key issues is to do with the ethical issues that emerge through the formation of a professional identity in that the intertwined and inseparable nature of making and teaching art have to be reconciled in relation to the needs of the learner. Tension exists within the Teacher-Artist identity in terms of balancing pedagogy and art, if the artist identity is prioritised too much it could become self-indulgent and the learner could suffer as a result.

The particular balance between artist and educator in the Artist-Teachers' identity effects the pedagogies that are used in the classroom. Each individual teacher must find equilibrium in their professional identity in order that they establish an effective teacher/artist persona. For an Artist-Teacher, their art practice forms an important component of the pedagogies they adopt in their educational work, it is intertwined and the two may not be separated. ArtistTeachers look for ways to nurture their own work; this is out of a strong belief in the impact 
of personal development on effective teaching. It is also inspired by teachers' enthusiasm to continually update their subject knowledge and to situate this within student's cultural understandings.

In the UK, the National Society for Education in Art and Design (NSEAD) has promoted the Artist-Teacher Scheme in relation to the improved quality of student learning that is observed when value is placed on teachers continuing art practice (Galloway, Stanley, Strand, 2006). Artist-Teacher is not only a UK phenomenon. Teachers who make art and Artists who teach are situated all over the world. Daichendt's (2010) interrogation of Artist-Teacher takes a US perspective, Atkinson (2011) looks predominantly at art education in the UK and Vella (2016) explores the ‘transnational influences and educational experiences’ (18) of Artist Teachers through a series of 21 interviews conducted with teachers in: Europe, Asia, North, South and Central America, Australia and the Middle East.

\section{Why Learn Art in Schools?}

Art in schools can provide an opportunity for students to learn creative skills as preparation to be artists or conversely art in school could be first and foremost an opportunity for dialogue and for students to develop their critical consciousness and conceptual skills. The art curriculum in schools often attempts to negotiate both these outcomes. Art teachers consider the methods of art production from the past along with propositions for the future in order to prepare students for the challenges and possibilities of cultural production in the C21st century. Part of the tension that exists in artist teacher identities comes from the fact that the purpose or function of art and education are different. Addison (2010) sees education as a transformative process, 'one in which people come to understandings of the world that help them to live their lives more richly and rationally’ (7). Art is about challenging our view of 
the world, offering alternative perspectives, engaging with art practice and contemporary theory in order to see the world anew.

Art education has aimed to enhance students’ knowledge and understanding of art in historical, conceptual, socio-political and of course practical and material terms. It has been dominated with a concern to induct learners into established forms of knowledge and introduce them to cultural objects as a means to form a relationship with the world around them. But art often subverts established forms of knowledge, always questioning the value of accepted knowledges and skills. Art itself is irreverent, often anti institutional, it offers new ways to connect with the world. Art practice needs an audience, it has to be disseminated, shared, made public and the ways of doing this are increasingly taking an 'educational turn' (Rogoff, 2008). These developments in pedagogic and artistic practices have led to one of the most prominent debates in our understanding of the role of Artist-Teacher and that is: how can we reconfigure the pedagogic objects of 'learner', 'ability', 'assessment' in ways that reconfigure the pedagogic space of art education? (Atkinson, 2011, 136). Art disrupts established relations and the Artist-Teacher continually evolves more effective pedagogical strategies to reconstitute the value of art in the world.

A teacher who also makes art has not necessarily completed a programme of postgraduate training. Many artists who teach have arrived at the educational component of their professional portfolio for economic reasons. Making art generates little income for living whilst delivering educational work can provide a salary on which to survive. For those not tied to economic necessity teaching can be simply considered an essential component of making art, Joseph Beuys' mantra for example that 'teaching was his most important work of art' (Lippard, 1973, 121). In order to explore the pedagogy that enables and supports artist 
teacher practice it is useful to look at the development of the contemporary definitions of Artist-Teacher.

\section{The History and Evolution of the Artist-Teacher in the early $21^{\text {st }}$ Century}

Programmes of postgraduate study that support Artist-Teacher's tend towards an open conception of the artist as educator. The term Artist Educator is used as a more general term which applies to educators working in a range of contexts. Such programmes of study have emerged over the last 20 years and are concerned with supporting and extending artist practice and critiquing or reflecting on pedagogy in relation to practice. They aim to reinvigorate and position teachers’ interwoven artistic and pedagogic practices through a critical engagement with contemporary art and theory. Some explore the potential of the Artist-Teacher to operate at a level beyond orthodoxy and toward a critical pedagogy. In the MA Arts and Learning, formerly the MA Artist Teacher and Contemporary Practices at Goldsmiths, University of London art practice is understood within a socio-political framework which serves to illustrate the position of artist educators within the early C21 critical pedagogical agenda. The expanded term 'Artist Educator' is important here as the pedagogical context includes community and cultural settings and not just the teaching of art in schools. Social justice agendas inform much postgraduate teaching in art education and explore the power of art in terms of the question; what can art do in the world? What is the power or force of art? The social aspect of art is explored through an in-depth understanding of cultural theories concerned with institutional pedagogy and public culture. This is used to connect the work of galleries and other cultural organisations with the work of the ArtistTeacher-Educators in school and community contexts.

Most art teachers want to improve their art practice, many feel that interacting with other artists would be beneficial. Gaining knowledge and understanding of art and confidence as an 
artist are also cited as key motivational factors for engaging with postgraduate study along with developing their teaching skills. Cusack (2016) observes that 'many art teachers $\{\ldots\}$ lament an abandoned practice and vow to "get back into it”' (in Vella, 2016, 32). A small number of those enrolled in postgraduate study also do so to enhance their career prospects.

There are Artist Teacher programmes for postgraduate study in the UK and the USA. In the UK, programmes are National Society for Education in Art and Design (NSEAD) recognised and have in the past been financially supported as well, although this funding has significantly declined since 2006.

Key beliefs that underpin the Artist Teacher scheme in the UK, taken from the Artist Teacher Scheme Evaluation published by the University of Warwick (Galloway, Stanley, Strand, 2006) are:

- that teachers’ personal development as artists can have a directly beneficial impact on their effectiveness as teachers and, as a result, on their students' learning and creativity;

- that the richness and complexity of contemporary fine art practice and the diversity of thinking and influences which inform it can enhance teachers’ subject knowledge and can enable them to make positive contributions to the delivery of the curriculum;

- that partnerships between major galleries and museums of contemporary art and prestigious institutions of higher education can provide the most stimulating locations and contexts in which to achieve these ends, can foster the raising of teaching 
standards and pupils' attainment and can assist cultural entitlement by creating greater access to the visual arts and culture.

Since 1999 the Artist Teacher Scheme (ATS) in the UK has helped galleries and higher education institutions to work in partnership to offer high quality professional development short courses, intensive summer schools, Masters courses and other events.

In the USA, the Artist Teacher Institute 'immerses classroom teachers, educators and artists in hands-on professional development workshops in the performing, visual, literary and digital arts led by master teaching artists’ (http://www.njati.org/, accessed 1 October 2017). The notion expressed here of a 'master teaching artist' reflects the vocational training for artists in the Renaissance. From the middle ages to the $19^{\text {th }}$ century, the 'atelier' model was vocational training for artists in North America and Western Europe. In the atelier, an apprenticeship approach was used where a 'master' artist worked with students and trained them on the job. This is a technical model devised to pass on skills from the experienced to the inexperienced maker.

The role of Artist-Teacher far predates contemporary programmes for postgraduate study. Since the Renaissance, there have been numerous attempts to rethink the paradigm of art education, many of which have been artist led initiatives and influenced by the Bauhaus (1919-1933). In the Bauhaus artists were always also teachers, this was an accepted component of their identity as an artist. The two were not separated out and the 'teacher' identity enhanced the 'artist' identity rather than being detrimental. Black Mountain college (1933) was an extension of this idea with whole classes built around a particular artists' practice. The paradigm of art education has grown out of an historical narrative in which the 
subject of art has been both transformative and instrumentalised at different times, with stages of conflict and resolution between the opposing views.

A number of art educationalists explored the idea of the teaching artist in the 1960's and 70’s:

'An artist would seem the most logical person to teach art' (Lowenfeld, 1975). This takes a positivist view that practicing artist have much to offer to the teaching profession. By extension this argument suggests that Artist-Teachers could achieve greater teaching success than those who no longer practice their art. This correlates with the NSEAD's supposition that the quality of students learning is enhanced when teachers still practice their art.

In 1958, Herbert Read wrote Education through Art and posits a more negative view; 'the idea of every teacher as an artist is impossible' (Read, 1958). This fatalistic view assumes that, despite the emphasis of earlier training the majority of artists working as teachers cease to practice their art.

Hausman wrote Concepts in Art Education (1967) which takes an evaluative approach to 'teaching success' which may be dependent on factors other than the artistic practice of the teacher. 'The skills and insights involved in making paintings, sculptures and prints do not necessarily extend into the realm of the personal skills and insights required for effective teaching' (Hausman, 1967).

Read (1958) also comments that 'the artist may not have time for teaching and the teacher will not have time for creating works of art'. We need however, to consider the definition of 
'artist' and 'teacher' and how their practices are defined and drawn together. For some the teaching is the art and for others the art cannot happen without teaching (Beuys, 1966;

Castillo, 2016).

\section{Teacher Identity}

Artist-Teacher identities are understood differently depending on the context. The idea of fixed, predetermined teacher identities is questionable or even contradictory (Atkinson, 2011). Artist-Teacher identities are constructed in relation to the learner, not in spite of them. The teacher and learner are inextricably linked and they impact on one another (Page, 2012).

Through dialogue, the teacher-of-the-students and the students-of-the-teacher cease to exist and a new term emerges: teacher-students with students-teachers. The teacher is no longer merely the-one-who-teaches, but one who is himself (or herself) taught in dialogue with the students, who in their turn while being taught also teach. They become jointly responsible for a process in which all grow. (Freire 1970, 53)

Authentic engagement should be sought by Artist-Teachers not mastery of a student by a teacher. Beginning teachers need to explore the identities of teacher, artist, learner. These are not fixed but flexible, in flux (Page, 2012). An art educator working in a school context would be described as an Artist-Teacher, whereas in a gallery, museum or community context they would be called Artist Educator or Facilitator. In each case practice is foregrounded and vital to producing effective learning outcomes. The construction of Artist Teacher/Educator/Facilitator is contentious in relation to other teacher identities because of the foregrounding of practice. This goes beyond subject knowledge and expertise and is a current and lived identity. Supporting practitioner teachers is important because of the complimentary nature of a teacher's own art practice and their professional knowledge of 
learning processes. Research (NSEAD, 2006) has shown that nurturing a teacher's own art practice improves the quality of student learning. Practitioner educators bring insight into the subject that comes through knowing as a form of doing. For example, a practicing artist in a gallery education context uses their practitioner perspective to interpret art works with visitors. Practitioners tend to explore with their students, they avoid simply downloading information to them. The balance between artist and teacher is constantly being renegotiated. Often in their early career artist teachers wear the two roles as separate identities. Having been trained as artists the pedagogic skills come later. Gradually, through experience and an openness to social justice agenda's the two begin to merge to form 'praxis' where strategies for art and for learning are brought together to precipitate change in the world.

\section{Defining the Artist-Teacher}

A number of writers have explored the composite identity of the Artist-Teacher (Atkinson, 2009; Daichendt, 2010; Addison and Burgess, 2010; Thornton, 2003).

The two positions identified by Thornton contrast the artist teacher with the teacher of art:

'Concept 1: An artist teacher is an individual who practices making art and teaching art and who is dedicated to both activities as a practitioner.

Concept 2: A teacher of art is an individual dedicated to the artistic development of students who does not necessarily practice as an artist' (Thornton 2003, 120).

Addison (2010) talks about the need for teachers of art and design to be informed about their subject and able to advocate for it in relation to their own art practice and in terms of the possibilities for art education in schools. The need for Artist-Teachers to position themselves and their beliefs within wider art, educational, philosophical and social practices. In 
Atkinson's (2011) conception of the Artist-Teacher the identities of artist, teacher and learner are all ideologically constructed. Atkinson uses a 'hyphenated form of artist-teacher $\{\ldots\}$ to signify a potential for dialectic’ (115), a reconfiguration of the artist-teacher identity in relation to art practice, learning and teaching. Daichendt states that the role 'has less to do with the professional activities of an artist and more to do with an active thinking process applied to educational situations’ (2010,65). Pringle (2009) talks about the ways in which Artist Educators locate learners as active makers of meaning, rather than passive recipients of ‘objective’ knowledge. In Hickman’s view, ‘from a social-constructivist standpoint, the [art] teacher can be seen as both facilitator and instructor' (113).

I have identified the importance of balance in relation to artist teacher identities. The ethical importance of taking account of the needs of the learner. The evolution of the Artist-Teacher identity through postgraduate study and the historical context from which this is drawn. All these factors are determined by particular conceptions of art education that have existed since the Renaissance. With Artist-Teacher identities always in flux how is the development of pedagogy that is appropriate the learner needs and the curriculum of study to be arrived at? I will go on to explore how the changing nature of contemporary art, it's creation and dissemination conspire to impact on Artist-Teacher pedagogy.

\section{What is the Pedagogy of the Artist-Teacher?}

The practices of Artist-Teachers in contemporary contexts reflect the changing nature of education in art. Teachers need to continually renew their subject knowledge, a characteristic that is nourished by being active practitioners in their field. By retaining pedagogic approaches that are adaptable to the changing sphere of activity, school based art can remain in sync with developments in art discourses such as the ‘educational turn’ (Rogoff, 2008; O’Neil and Wilson, 2010), 'participatory art' (Bishop, 2012) and 'relational aesthetics' 
(Bourriard, 1998) which I will discuss in relation to their impact on pedagogy later in this section. Approaching the discipline with such openness allows for its dispositions to be reconceptualised and means that classroom practices and pedagogy can engage with emerging concepts rather than only focussing on the art of the past. This happens most effectively when Artist-Teachers engage with the art on show in local cultural contexts and also with their own engagement as producers of contemporary practice.

'The actions, philosophies, and contexts we work with as artists inform much of what we know and teach' (Daichendt, 2010, 3).

\section{The Social Production of Art}

Art objects are not created in isolation, they are the product of the society from which they are produced. The pedagogy of artist teacher is socially situated, it responds to both the social context of the production of art and the needs of the learner. Art is 'increasingly developed in social situations through community and public art' where attitudes and social practices are changed through participation (Addison, 2010, 9). For Bourdieu (1984) art is a social process, a person's social status is determined in part by the art and culture they choose to look at, buy and engage with. Through such choices, those with taste and knowledge are separated from those without. This is essentially a discourse about power, many other discourses have explored the relation between art and power (Baudrillard, 2005), and in terms of cultural hegemony (Gramsci, 1992).

No longer central to the modernist belief about the purpose of progressive education, art education is currently reinterpreting itself. In so doing there arises a real opportunity to tear up social distinctions and confront young people with ideas through their engagement with art; to develop inclusive, socially engaged and critical practices (Addison, 2010, 10). 
The attitudes to knowledge and its' production through art education reflect the social aspects of art as a subject of study and its responsiveness to the society from which it is created. The predominant epistemology surrounding art education is informed by these social processes. Modernist discourses have influenced radical changes in art education and generated contrasting points of view in terms of educational outcomes. These range from art as a positive and transformative force to the ideas of art as an instrument of power (Addison, 2010, 10). When constructing pedagogy for the arts the dominant assumption is that knowledge is constructed through the interaction between art objects and people and that a negotiation of knowledge between the subject of art and the individual learner exists. Part of the role of pedagogy within this negotiation is to take account of the needs of the learner. Where art can be viewed as a social construct, education is more centred on the individual and their development. Artist-Teachers in contemporary settings often take learning to be experiential, democratic, social, transdisciplinary and driven by the individual (Vella, 2016). The purposes of art education are variously described from: drawing out inherent qualities (Ault and Beck, 2006), to questioning students' understanding of themselves and the world (Daichendt, 2010), and 'increasing [students] ability to make informed choices in shaping the environment in which they live’ (Addison, 2010, 8).

Art teacher pedagogy responds to the contemporary discourses of art which as a subject has been shaped, opened-up and connected to the world through the fields of philosophy, social science, psychoanalysis and cultural theory. Art teacher pedagogy is drawn from these discourses along with the art that is on display in the cultural institutions of the time. In addition, pedagogy is inevitably influenced by an Artist Teacher's own practice and their approach to education. Key art historical movements affect what is taught and how. For 
example, in the Bauhaus teaching methods were drawn from artistic guidelines for the production of art, in the Art Schools of the time, these were transformed into formulas for making art and created a discipline through which art could be taught (Daichendt, 2010, 4). Modernist discourses exemplify, on the one hand, the idea of the art object being purely visual and on the other the art object as cultural signifier where context, critique and concept are essential components of the work. This creates a tension in terms of pedagogy, does a teacher impart skills for making or skills for critique? And furthermore, do learners need to learn to make art at all. Can they not simply come up with ideas and employ someone else to fabricate the work: a question often asked of me by Undergraduate students nearing assessment. The answer to this is not altogether clear. The form of the 'readymade' problematizes the idea of the art object, and, in so doing questions the conception of what art and artists are and do. Where art education has traditionally centered on developing technique and aptitude designated by the values of contemporary culture. The 'readymade' removes any need to have manipulative skills for making work. 'Readymades' also question the idea of art in a capitalist mode of production and the predominance of the art object as something of economic value. A readymade like, for example, Duchamp’s ‘Fountain’ (1917) could be bought from a hardware store for a modest amount of money. However, as an artwork, signed by the artist using the pseudonym R. Mutt it was worth \$1185,000 when it was sold in 2002. Taking account of such changes in the beliefs and practices that guide our thinking about art introduces a critical dialogue which provides rich form and content to art education in schools and colleges.

At the end of 20th and early $21^{\text {st }}$ Century the emergence of post-modernism underlines art as a discipline that is closely connected to socially constructed hierarchies. Using art to highlight systems of social stratification presents a real opportunity for contemporary art 
teaching. Here is a chance to use art to consider the structure of society and to reveal the systems of power that are at play. Art taught in classrooms has the potential to be both critical of existing systems and generative of new ideas. This is simultaneously a romantic notion drawing from the transformative potential of art whilst also aligned with utopian ideas that critique the power relations of existing systems. Postmodernism did just this by providing an approach to art which borrowed from high and low culture and attempted to rip apart the tensions between them. Postmodernism had a 'levelling effect' on culture according to Beech (2006). However, whilst postmodernism was a popular theory, the amalgamation of cultural forms worked when it was related to images but it didn't work when applied to society as it suppressed the politics of cultural division. It made it seem that high and low cultures could easily merge, that we were living in a classless society. In fact, social cohesion is much more difficult to achieve than this.

The postmodernists' reconciliation of culture’s deep historical rift came too early and too easily. If the crudeness of the concept means it's advisable to forget elitism, it is not acceptable to forget the social process of cultural distinction that it seeks but fails to explain (Beech, 2006).

\section{Learning as Social Practice}

So, to turn again to the effect of art education on the individual and away from the broader social issues that can be explored through it. This is a means to reconcile pedagogy in relation to practice and in turn to underline the importance of the Artist Teacher's own practices in relation to their development of pedagogic constructs. Learning is an inherently social activity, 'schools are social institutions' (Burgess, 2010, 68). Burgess (2010) talks about the construction of learning communities through collaboration and the importance of a commitment to continual shared investigation in socially engaged pedagogy (69). 
In their (2006) essay ‘Drawing Out and Leading Forth’, written for Manifesta 6, Notes for an Art School, Julie Ault and Martin Beck talk about 'education as a process of 'drawing out' qualities already inherent in the individual; and, secondly, as a 'leading forth', which is understood as a form of guiding individuals into certain social contexts. They draw our attention towards a conflict that exists within creative education between the individual and the social. They talk about the 'individuality', 'freethinking', and 'autonomy' of art education in contrast to the realities of artistic production, which is social, and 'embedded into particular histories and contexts'. This tension is part of the equitable situation in which art educators strive to perform where they engage with the social context of art whilst remaining mindful of the highly specific context in which each individual learner interacts with new knowledge. Pedagogy is constantly operating on a kind of 'sliding scale' between the learner and the subject of study where the educator acts as a mediator. Such mediation is predicated by the fact that learning is not always easy and that the struggle can be embraced as an important part of a significant realization, but, the struggle could equally be humiliating for the learner. To navigate this 'sliding scale' an experienced educator decides whether to push the enquiry, the engagement, closer to the artwork and risk over challenging the learner or, to remain with the learner and their initial thoughts and perceptions. This decision is taken according to the learners' perceived ability and their resilience to challenge. It takes a lot of experience to make such a judgement as it is a navigation of ethical constraints: the educator has a moral obligation to protect the learner's vulnerability. Such skills in employing pedagogic strategies effectively require a strong teacher identity.

Most learning strategies for art education fit within a social-constructivist approach. Art activities are often social and involve group work. Educators acknowledge that learners come 
with their own lived experiences and that these experiences form part of the way that they look at art. Social-constructivism places great importance on the role of language in the learning experience 'in helping [learners] to understand new concepts and ideas' (Hohenstein and King, 2007). A balance needs to be struck between what is to be learned and how the learner will come to understand it. Constructivism has been criticised for placing too much emphasis on the activity of the learner and too little on the knowledge to be learned (Maher, 2004; Meszaros, 2006). This problem is a constant issue for facilitator/teachers of art. On the one hand, strong relationships of trust need to be built with students and therefore educators stay close to the learner, but for learners to move beyond personal observations and adopt critical positions in relation to the art work the educator/interpreter has to situate themselves within proximity of the art work as well. Vygotsky’s 'zone of proximal development' describes this process along with a need for 'scaffolding' the learner, also described by Vygotsky (1962, 2003).

A dialogical construct exists between learner, educator and artwork. For example, a facilitator is constantly making decisions about how to engage their students. If we imagine that there is a scale where an artwork exists at one end and the maker or viewer at the other. With a confident student the facilitator, metaphorically, stays close to the art and through questioning draws the participant out of their subjectivity and 'into' the work and its inherent challenges. With a more reluctant learner, the dialogue is more conversational and stays closer to the viewer: looking for 'hooks' to emerge between their subjective experience and the artwork itself.

\section{Critical Pedagogy}

Teachers teach critical thinking, this uses philosophical skills and a disposition of openness to new ideas. If a teacher were to become too set in their pedagogy they would themselves lose 
the ability to approach the world critically, teaching may become didactic. If the knowledge that is imparted takes the learner into account and starts from where they are then how do we decide what to teach?

Addison (2010) discusses the idea of education as a form of social and political practice that effects young people's relationship with the wider culture. He talks about the emancipatory project of critical pedagogy as a 'radical alliance' (114), a means to achieve a more democratic society. The conception of critical pedagogy, discussed in Duncan-Andrade and Morrell (2008) and Darder, Baltodano and Torres (2009), underlines the importance of active projects that are negotiated by learners and facilitators together. Critical pedagogy leads to an approach that empowers young learners because of the emphasis on preparing the educator to teach by heightening their critical perceptions of the world and the inherent inequalities that are often taken for granted or left unseen by the educational establishment. Critical pedagogy is a term of reference initiated in the United States and referring to the practice of radical educators who engage critically with the impact of an unequal society on young people from disenfranchised groups. 'During the early 1900’s, Dewey sought to articulate his pragmatic philosophy and expand on the idea of community to explain the purpose of education in a democratic society' (Darder, Baldotano and Torres, 2009: 3). Whilst Dewey has been criticized because of his faith in creative intelligence and 'underestimating the sociopolitical and economic forces that shape inequality and injustice’ (Darder et al., 2009, 3). It is important that by linking the ideas of individual and social intelligences with the discourses of democracy and freedom, Dewey provided philosophical constructs that have been significant in the evolution of critical pedagogy (McLaren, 1989). Educational institutions are 'part of the existing social and political fabric that characterises the dominant society' (Duncan-Andrade and Morrell, 2008, 23). 
Artist Teachers have much in common with Duncan-Andrade and Morrell's (2008) definition of critical thinkers who believe 'that any genuine pedagogical practice demands a commitment to social transformation in solidarity with subordinated and marginalised groups' (Duncan-Andrade and Morrell, 2008: 23). Art Education is a form of critical pedagogy because of the commitment to the concept of 'praxis' where teacher and student are working together and in some ways emancipating the learner, freeing them from the inequality and restrictions that they may otherwise encounter. Luis Moll (2000) refers to 'funds of knowledge' that 'draw from the knowledge that students bring with them to school, knowledge that is often not in their textbooks but is acquired from the streets, family, cultural traditions, youth culture and the media’ (Duncan-Andrade and Morrell, 2008: 9).

\section{The Impact of Contemporary Art Practices on Pedagogy}

Some contemporary arts professionals feel that art in schools can be out of touch with contemporary art making practices (Downing and Watson, 2004). Social interaction and purposeful participatory practices are difficult to integrate into an individualistic curriculum where students are tested alone and not assessed in groups. In schools and colleges, systems of assessment mean that object and image based outcomes become the measure of student progress. A situation that is contrary to the more social artmaking practices that have become widely established forms since an altogether more participatory relation with the art object emerged at the end of the 1990's in the form of 'relational aesthetics' (Bourriaud, 1998). This is a term that describes an 'art of the generic social encounter' according to Beech in O’Neill and Wilson (2010, 49). Bourriaud (1998) describes it as 'a set of artistic practices which take as their theoretical and practical point of departure the whole of human relations and their social context, rather than an independent and private space' (113). Here artists are facilitators rather than makers and art is seen to be information exchanged between the artist 
and the viewers. In O’Neill and Wilson’s (2010) book 'Curating and the Educational Turn’ a collection of essays explores the new terrain of art that has been emerging over the last 10 years and has in some practices replaced the art object altogether. In their introduction, they describe the way that 'curating increasingly operates as an expanded educational praxis' (ibid.: 12). They propose that, 'curating, and art production more broadly, have produced, undergone or otherwise manifested an educational turn' (O’Neill and Wilson, 2010: 12). But adopting the strategies for education: talks, discussions, symposia does not necessarily lead to knowledge production and learning. They don't automatically place the curator in the role of educator of the public, in fact they often simply construct the educational process as the object of curatorial production. What they do productively create are the conditions for ambiguity, enquiry and conversation to take place.

So, as I have discussed, the reception of the art object has and is changing and with it the pedagogies that surround it. This leads back to the fundamental question for Artist-Teachers. What to teach and how to teach it? Art is not a subject with a specific lexicon of facts like science or mathematics. The field of art production is always changing, and the art curriculum reflects such changes. As a result, what to teach is not prescribed by a syllabus and must be decided by each individual teacher within the guidelines set out by the National Curriculum in the UK and the Content Standards (2008) in the USA.

\section{Practice Research}

Many Artist-Teachers consider their practice as a form of research, this is sometimes referred to as ‘Practice Research’ (Bolt, 2007; Sullivan, 2008; Nelson, 2013). A form of enquiry which allows for tacit knowledge, complex, operational knowledge that is difficult to articulate or pass on because of its complexity and intuitive or embodied knowing. This kind of knowledge could be described as 'phenomena' and not conducive to traditional forms of 
research particularly quantitative investigation. Rather than using research as a means to certainty, art research opens up unforeseen possibilities. Practice research provides a good methodological approach to exploring these forms of knowledge experientially.

Practice research is interdisciplinary and employs diverse methodologies which enable enquiry across art making and pedagogic practices. Practice research re-configures how a given subject is constituted and forms part of a cycle of action and reflection that supports the production of new ideas, objects and/or events. Sullivan (2008) asserts that; 'when artistic practice is used within the context of inquiry, there is an investment in the potential that insight may emerge as a reflexive action sparked by a creative impulse that can help to see things in a critically different way' (242). Practice research questions our epistemological approach and our beliefs about knowledge production or reproduction.

\section{To Teach Skills or Aptitudes?}

In the atelier model the master artist would teach the skills associated with their own artistic work. Students were apprentices and would learn the skills of the master. A contemporary art curriculum encompasses a much wider set of aptitudes and dispositions than just one person's skill set. This is partly predicated on a teacher's willingness to support a whole range of interests that learners display along with practical making and thinking skills. Art is an inclusive, learner centred subject. Students receive a grounding in practical making skills as well as the disciplines of critical and conceptual thinking. Some of these may be drawn from the Artist Teacher's own practice but many will be taught in relation to the work of other artists. Therefore, the teacher must be knowledgeable about their subject beyond the confines of their own art specialism. 
Educational establishments maintain a core philosophy that informs the ways in which they teach art. Such philosophies have changed over the years, for example, in the Renaissance, this was to do with mastering specific expertise to a high standard. From the 1960's it was the ‘individuals’ capacity for expression, their use of intuition and imagination, and their pleasure in making which [have] contribute[d] to as healthy society’ (Hickman, 2010, 57). A significant shift in the teaching of art happened as a consequence of the 'Coldstream Report' (1961) in the UK. Coldstream examined the polarities occurring in teaching art in schools and affected curriculum development in art education. Coldstream advised on the development of art and design history to be taught alongside studio practice linking the subject of art and design to academic disciplines. This had a significant influence on art pedagogy in the classroom and made art into a more academic subject and written components became a standard part of assessment.

In today’s art schools the philosophy of art education remains in constant flux, being rethought continually. As Hickman (2010) observes, 'the very nature of art as a dynamic and fluid phenomenon, means that previous debate often needs to be revisited' (7). The idea of a specific doctrine is unheard of and 'the absence or rejection of a central philosophy is the philosophy' (Daichendt, 2010, 4). Daichendt (2010) goes on to note 'the rule is that there are no rules’ (4).

So, what do you teach? Do you teach making skills? If so which ones? Often this is determined by and drawn from the particular expertise of the teacher's in the department. In many ways this approach is similar to the atelier model where the masterful expert passes on their expertise to the students. Hickman (2010) draws our attention to developmental, constructivist approaches 'based upon the learner constructing knowledge and understanding 
by assimilating new information (for example from a teacher) and synthesizing it' (113). He advocates the need for 'structure and guidance' and the need to teach the 'relevant skills at an appropriate time in their development' (113). Some contemporary Artist Teacher's see the apprenticeship approach or the teaching of specific skills as too close to the 'banking model' of education introduced by Freire (1970) where a student is a kind of empty vessel waiting to be filled with knowledge by the expert teacher. Instead they engage in alternative approaches in which the outcome is not predetermined from the outset, such a process of enquiry takes place alongside their students (Atkinson, 2011, Fortnum and Fisher, 2013). This is a contentious area in art education that has caused deep divisions in the modes of delivery employed.

\section{The Knowledge Paradigm}

Part of this contention is around attitudes to knowledge where art is employed as a means to be speculative to enquire and to search for understanding. To adopt a non-didactic approach and work with what is not yet known calls into question art's relationship to knowledge and discourses of knowledge production. As Fisher asserts; 'art draws us into a space of not knowing, a way of thinking in the widest possible sense' (Fisher, 2013, 13). Not knowing is about experimental forms of knowledge, having to find things out and feeling fine about not having all the answers. It is concerned with having provisional ideas, supposing. A process to be savoured rather than overcome in the search for singular facts. What's important in the teacher student relation is not knowing together, going on a shared journey, not trying to second guess an answer that the teacher or facilitator has already identified.

Atkinson (2013) opens-up ideas that are important for Artist Teachers when faced with the problem of what to teach and how to teach it. In-particular that notions of education are inherently reproductive, such as 'the need to induct learners into established forms of 
knowledge and skill (135)', ones which have cultural value. Atkinson offers an alternative approach when he points towards the idea of learning as productive, not reproductive, where rather than being constrained by prior goals, 'old' objects of learning are transformed. In talking about the reconfiguration of pedagogical objects, 'learner', 'ability', ‘assessment' and their transformation in new functioning contexts, art pedagogy can be a productive domain rather than simply one which reproduces the skills and techniques that have gone before.

A productive approach to knowledge stems from the hermeneutical approach proposed by Gadamer (1960) where the reader 'participates just as much as the author does in putting together meaning or in creating the aesthetic experience' (Gallagher, 1992: 10). This approach seeks to define interpretation as a ‘cultural conversation’ (10) where meaning is produced rather than reproduced. Understanding the way in which individuals come to know in this way is in opposition to the conservative hermeneutics of Hirsch (1965) which is concerned to arrive at a specific and pre-existing interpretation, new knowledge, and therefore must be objective. Hirsch argues that meaning is fixed within the object and that we should not confuse 'meaning' with 'significance’ (Hirsch, 1965: 498). Gadamer argues that it is not possible to make an entirely objective interpretation and that the interpreter plays an intrinsic part of the meaning that is made (Gallagher, 1992).

The myth of Hermes, from which the study of hermeneutics is drawn, can be applied to our engagement with art, our role as facilitators of learning and our understanding of our predicament as human beings: 'our perpetual need for understanding and guidance, our sense of trying to find, follow and keep to a path, the experience of 'being-drawn-on', of 'beingexcited-by' the anticipation of where a dedicated route might take us' (Heywood \& Sandywell, 1999: 6). Art educators are familiar with learning processes where an initial 
'spark' arouses interest, motivates further investigation and leads to different paths that such investigations can take. Gallagher (1992) uses hermeneutical principles to explicate this learning experience. Hermeneutics after the 1700’s was distanced from didactic pedagogies when Schleiermacher 'excluded exactness of explication' from the realm of hermeneutics (Gallagher, 1992, 9). Conversely Gadamer is aligned with this when he supposes that 'every attempt at reproduction involves a production of new meaning, and thus, strict reproduction is not possible’ (Gallagher, 1992: 15).

So, is the purpose of education to empower learners and engage them in a journey of discovery where the outcome is not predetermined? Or is it to acculturate them into predetermined modes of thought? This debate continues to divide the field of art pedagogy. Most educators in my experience find some middle ground where some didactic teaching is combined with experiential and open-ended modes of learning where the student is supported in their own self-directed enquiry. The knowledge that the teacher brings is not obsolete, they are an important part of the learning community. As Biesta (2006) remarks, 'what I see as essential for education, [...] is the presence of a teacher, not just a fellow learner or a facilitator of learning, but as someone who [...] has something to bring to the situation that is not already there' (6).

\section{Conclusion}

Artist-Teachers are concerned with the learning individual and with art as the object of study. The purpose of teaching art can either prioritise empowerment of the learner or acculturate them into new cultural forms. Artist-Teachers aim to bring an element of each of these into their pedagogies. They attempt to use art education to enhance the knowledge and understanding of art as they purposefully move away from education as a means to induct learners into established forms of knowledge and into epistemological practices that value the 
knowledge that the learner brings. To achieve this the Artist-Teacher's identity must strike a balance between practitioner and educator. It is therefore important that educators remain involved in contemporary practice as makers and as cultural consumers.

An ethical dimension divides the principles of practice that exist between art and art education in relation to the needs of the learner. For the teacher, more effective pedagogical approaches continually evolve and for the artist, art continues to disrupt established relations. This has implications for the identity formation of the Artist-Teacher, the training that they undergo and the pedagogical question of what to teach and how to teach it? To respond to this, I have explored key developments in contemporary art practice in an attempt to demonstrate how Artist-Teachers use their knowledge of the changing world of contemporary art to create new strategies. I have tried to draw together the key theoretical paradigms that inform our understanding of art practice and art education to address Atkinson’s (2011) speculation concerning the need to reconfigure the pedagogic space of art education and reconsider what constitutes a learner, what ability is and how it is affected by new forms of art practice which do not require the implementation of specialist techniques. How then can we assess or form judgements about the value of art objects?

The use of Artist-Teacher's practice as a catalyst for pedagogy is enhanced by the link between critical pedagogy and practice research. Both these discourses support risk and experimentation with new techniques and materials but also encompass social or political risk, something which is currently avoided in schools. To support teacher/educator development in these areas, continuing professional development and postgraduate study are broadening out their cohort of students in terms of the recruiting people from a range of educator/facilitator/teacher backgrounds. Student's open up discourses about what art can do 
and what education can do by troubling and rupturing art's role in the world. This enables them to explore different configurations of Artist-Teacher and meet a range of needs: from a focus on practice, a priority for pedagogy, or to explore the system in which they work in order to build a theoretical position from which to articulate strategies for change.

Future for artist teacher

In my view an Artist-Teacher of the mid C21st will both engage learners in a journey of discovery, where the outcome is not predetermined, and teach them pre-existing modes of practice. This could be achieved by following the model of critical pedagogy where active projects are negotiated by learners and facilitators together. Where what is to be learned about art is identified collectively and learners come to understand it in ways that are creative, authentic and meaningful to them. This involves treating arts and culture as a lived experience not simply something from the past to be found in galleries and museums or copied in the art classroom. Young people should be encouraged to understand the idea that they are part of culture, it doesn't just happen to them, they create it in many different forms. Art Education needs to embrace these forms, to support young people in using their creative practices to develop their own ideas. Art teaching involves imparting a wide range of skills and supporting young people to use them in ways that are meaningful. Such variety may prevent art as a subject from becoming fixed around particular cultural forms and limited to the ones that are familiar to the art teacher. To achieve this art teacher skills have to be nurtured and nourished with new practices and techniques producing an even greater need for continuing professional development to keep the range of processes relevant to the cultural forms and creative activities that young people engage with. 
Despite the structural changes in education that have led to the erosion of arts subjects within the school curriculum the arts seem surprisingly resilient. The future for art education depends largely on the increasing development of creative and critical thinking in other subjects. Developing creative skills is not only a mandate for arts educators. If creative practices are adopted more consistently in many curriculum areas then art teachers can engage more fully with their subject, it’s historical, social and political context, the material culture from which art is formed and students using their critical and conceptual thinking skills to explore and contribute to the world in which they live. Whilst the process of art education has become more conceptual it is still firmly linked to creative practices involving divergent ideas and multiple viewpoints.

How art education and the role of Artist-Teacher develops in the future is largely an economic issue. In many ways the current conception of Artist-Teacher as one person who delivers multiple skills to their students is a product of the austerity in spending that has affected global economies in the early twentieth century. Cuts to funding for the arts and to public education have created financial constraints which mean that there are less opportunities to work with visiting artists than there were at the end of the C19th. This effect of austerity has been damaging to the teaching of art at school and at University level as it reduces the range of processes that students have access to. This economic or market model for art education points pragmatically towards the conception of the Artist-Teacher as 'masterful' and possessing a wide vocabulary of skills from which to teach. This is perhaps a return towards the atelier model. I would prefer to see a collaboratively taught, socially embracive, critical practice which places the learner at the centre of the journey of discovery. 


\section{References}

Adams, J. (2007), Artists Becoming Teachers: Expressions of Identity Transformation in a Virtual Forum. International Journal of Art \& Design Education, 26: 264-273. doi:10.1111/j.1476-8070.2007.00537.x

Addison, N. and Burgess, L. (2003) Issues in Art and Design Teaching Ed., Routledge London and New York.

Atkinson, D. (2011) Art, Equality and Learning: Pedagogies Against the State, Sense publishers.

Ault and Beck (2006) Notes for an Art School, Manifesta 6 School Books, was commissioned by the International Foundation Manifesta in Amsterdam and Manifesta 6 in Nicosia.

Baudrillard, J. (2005) The Conspiracy of Art: Manifestos, Interviews, Essays: Manifestos, Texts, Interviews (Semiotext(e) / Foreign Agents). 20 Sep 2005.

Beech, D.(2006) Forget Elitism. Art Monthly, 296, Exact editions.

Biesta, G. (2013) The Beautiful Risk of Education. Routledge: London and New York. Bishop, Claire (2012) Pedagogic Projects in: Artificial Hells,Participatory Art and the Politis of Spectatorship. London, New York, Verso.

Barrett, E., Bolt, B. (2007) Practice as Research: Context, Method, Knowledge. I.B.Tauris. Bourdieu, P. (1984) Distinction: a social critique on the judgement of taste Routledge. Bourriaud, N. (1998) Relational Aesthetics Les Presse Du Reel.

Coldstream (1961) First Report of the National Advisory Council on Art Education, London, HMSO.

Daichendt, J. G. (2010) Artist Teacher: A Philosophy for Creating and Teaching. Intellect: UK/USA.

Darder, A. Baltodano, Marta P. Torres, R. D. (2009) The Critical Pedagogy Reader. London and New York: Routledge. 
Downing, D. and Watson, R. (2004). School Art: What's in It? Exploring Visual Arts in Secondary Schools. Slough: NFER.

Duncan-Andrade, J, M, R, Morrell, E. (2008) The Art of Critical Pedagogy. New York: Peter Lang Publishing Ltd.

Fortnum R and Fisher E. (2013) On not knowing how artists think. UK: Black Dog Publishing.

Freire, P. (1970) Pedagogy of the Oppressed. London: Penguin.

Gadamer, H., G. (1960) Truth and Method, Crossroad Press, New York.

Gallagher, S. (1992) Hermeneutics and Education. Albany: State University of New York Press.

Galloway, S., Stanley, J., Strand, S. (2006) The Artist Teacher Scheme Evaluation 2005-2006 Final Report. National Society for Education in Art \& Design 2006.

Hausman (1967) Concepts in Art Education

Heywood, I. and Sandywell, B. (Eds.)(1999) Interpreting Visual Culture: explorations in the hermeneutics of the visual, Routledge London and New York.

Hickman, R. (2010) Why We Make Art and Why it is Taught. Intellect: UK, USA.

Hirsch, Jr., E., D. (1965) Truth and Method in Interpretation, Review of Metaphysics, Crossroad publishing.

Hohenstein, J. and King, H. (2007) 'Learning in and out of the classroom', in Becoming a teacher: Issues in secondary teaching, 3rd edition pp. 163-174.

Lippard, L. R. (1973) Six Years: The Dematerialization of the Art Object from 1966 to 1972. p. 121, University of California Press.

Lowenfeld, (1975) Creative and Mental Growth. Macmillan. 
Mezaros, C., (2006) Now THAT is evidence: tracking down the evil 'whatever' interpretation, Keynote Address at the Visitor Studies Association Conference, July 2006, Grand Rapids, Michigan.

McLaren, P. and Hammer, R. (1989) Critical pedagogy and the postmodern challenge in Educational Foundations 3(3): 29-69.

Nelson , R. (2013) Practice as Research in the Arts: Principles, Protocols, Pedagogies, Resistances, Palgrave Macmillan UK

O’Neill, P. \& Wilson, M. (2010) Curating and the Educational Turn, Open Editions, De Appel Arts Centre, Amsterdam.

Page, T. (2012), A Shared Place of Discovery and Creativity: Practices of Contemporary Art and Design Pedagogy. International Journal of Art \& Design Education, 31: 67-77.

Pringle, E. (2009) 'The Artist as Educator: Examining Relationships between Art Practice and Pedagogy in the Gallery Context', Tate Papers, no.11, Spring 2009, http://www.tate.org.uk/research/publications/tate-papers/11/artist-as-educator-examiningrelationships-between-art-practice-and-pedagogy-in-gallery-context, accessed 2 October 2017.

Read, H. (1958) Education through Art. Faber \& Faber.

Rogoff, Irit (2008) Turning; e-flux Journal 0/2008, eflux.com, e-flux, Web. 9. Sept. 2012 http://www.e-flux.com/journal/turning/.

Sayers, P. (1970) Dissertation thesis for Masters in Art Education, Leeds College of Art. Sullivan, G. (2008) The Necessity of Studio Art as a Site and Source for Dissertation Research

Article in International Journal of Art \& Design Education 27(1):4 - 18 - January 2008. Thornton, A. (2011), Being an Artist Teacher: A Liberating Identity?. International Journal of Art \& Design Education, 30: 31-36. doi:10.1111/j.1476-8070.2011.01684.x 
Vella, R. (2016) Artist-Teachers in Context: International Dialogues. Sense Publishers:

Rotterdam, Boston, Taipei.

Vygotsky, L. V. (1962) Thought and Language. Cambridge, MA. MIT Press.

Vygotsky's educational theory in cultural context [electronic resource] / edited by Kozulin, A.

... [et al.] Cambridge: Cambridge University Press, 2003.. xiii, 477 p. : ill.

Wygant F. (2015) A Conversation with Sir Herbert Read, Art Education. Pages 32-36 |

Published online: 29 Dec 2015

\section{Bibliography}

Adams, J., Worwood, K., Atkinson, D. D., P., Herne, S., \& Page, T. (2008).

Teaching through contemporary art: A report on innovative practices in the

classroom. London: Tate Publishing.

Atkinson, D and Dash, P. (Eds.). (2005). Social and Critical Practices in Art Education. Stoke on Trent, UK, and Sterling, USA: Trentham.

Atkinson, D. (2002). Art in Education: Identity and Practice. Dordrecht/Boston/London: Kluwer.

Hickey-Moody, A., Palmer, H. \& Sayers, E. (2016) Diffractive Pedagogies: Dancing Through Materialist Imaginaries. Gender and Education Vol. 27. 6.

Sayers, E. (2014). An 'Equality of Intelligences’: Exploring the Barriers to Engagement with Modern and Contemporary Art in Peer-to-Peer Workshops at Tate Modern iJADE, Volume 33, Issue 3, 358-361. ISSN1476-8062. 
Sayers, E. (2011). Investigating the impact of contrasting paradigms of knowledge on emancipatory programmes for young people, iJADE Volume 30, Issue 3, 409- 422. ISSN 1476-8062.

Schwabsky, B. (2004). Vitamin P. Phaidon Press: London

Sullivan, G. (2007). Art Practice as Research: Inquiry in the Visual Arts. Sage: New York. 